\title{
PEMBELAJARAN KONSTRUKTIVISTIK MENINGKATKAN CARA BERPIKIR DIVERGEN SISWA SD
}

\author{
Haryanto \\ Universitas Negeri Yogyakarta \\ Email: haryan62@yahoo.co.id
}

\begin{abstract}
Abstrak
Penelitian ini bertujuan untuk menemukan model pembelajaran konstruktivistik yang efektif untuk mengembangkan cara berpikir divergen dan konvergen siswa SD. Metode penelitian yang digunakan untuk mencapai tujuan tersebut adalah pendekatan R\&D (Research and Development) model Borg and Gall. Hasil penelitian adalah; 1) pembelajaran di SD Sleman Iebih dominan mengembangkan cara berpikir konvergen daripada cara berpikir divergen, 2) model pembelajaran yang sering diterapkan guru adalah model pembelajaran ekspositori, yang menjadikan metode ceramah sebagai metode utama, 3) penerapan model pembelajaran konstruktivistik mampu meningkatkan cara berpikir divergen dan konvergen siswa SD, 4) penerapan model pembelajaran konstruktivistik mampu meningkatkan aktivitas belajar siswa SD, 5) penerapan model pembelajaran konstruktivistik mampu meningkatkan hasil belajar siswa SD, dan 6) sistem evaluasi portofolio mampu meningkatkan aktivitas belajar siswa SD.
\end{abstract}

Kata Kunci: konstruktivistik, divergen, konvergen

\section{CONSTRUCTIVIST LEARNING IMPROVES DIVERGEN THINKING ON ELEMENTARY SCHOOL STUDENTS}

\begin{abstract}
This research aims to find effective constructivist learning model to develop divergent and convergent thinking of students in elementary schools. This is a research with R\&D method (Reseach and Development) of Borg and Gall model. Results show: 1) Learning activities in Sleman elementary schools is dominated with convergent thinking instead of divergent, 2) Most teachers implement expository learning as their main learning model, 3. The implementation of constructivist learning model improves divergent and convergent thinking among elementary school students, 4 . The implementation of constructivist learning model improves learning activities among those students, 5). Constructivist learning model heightened students' learning result, 6) Portofolios evaluation system increases students learning activities.
\end{abstract}

Keywords: constructivist, divergent, convergent

\section{PENDAHULUAN}

Telah menjadi tradisi di kelas-kelas kita bahwa para guru kita dalam merancang proses pembelajaran belum mampu menciptakan kondisi belajar yang memungkinkan potensi siswa berkembang secara optimal. Apa yang terjadi di kelas-kelas tidak lebih dari latihan-latihan skolastik, seperti mengenal, membandingkan, melatih, dan menghapal, yakni kemampuan kognitif yang sangat elementer, di tingkat paling rendah (Winarno Surakhmad, dkk., 2003:25). Peningkatan belahan otak kanan dan kiri secara seimbang 
belum terjadi. Proses pembelajaran lebih banyak mengembangkan belahan otak kiri yang cenderung berpikir konvergen, dan jarang sekali menyentuh wilayah belahan otak kanan yang cenderung berpikir divergen.

Kritik lain yang sering dikemukakan oleh para pengamat pendidikan pada sekolah kita adalah masih dominannya peran guru dalam proses pembelajaran di kelas. Penggunaan metode ceramah menjadi kebiasaan yang sulit diubah. Proses komunikasi dalam pembelajaran terjadi hanya searah (guru-siswa), sehingga berdampak pada tidak optimalnya pengembangan potensi siswa baik dari aspek kognitif, afektif, maupun psikomotorik.

Ketidakberanian siswa untuk bertanya, mengajukan pendapat, dan berdiskusi di dalam kelas perlu dicarikan solusinya agar proses belajar di kelas lebih bermakna bagi siswa. Semakin banyak siswa yang bertanya, mengajukan pendapat, dan berdiskusi, semakin membantu guru untuk memahami jalan pikiran siswa, dengan asumsi bahwa bertanya hakekatnya adalah berpikir, sehingga guru termotivasi untuk memberikan penjelasan lebih luas dan rinci sesuai yang diharapkan siswa.

\section{Berpikir Konvergen}

Berpikir konvergen yang bersumber dari fungsi belahan otak kiri, merupakan cara berpikir vertikal, rasional, metodis analitis, dan linier menuju pada suatu kesimpulan tertentu. Orang dengan kecenderungan berpikir secara konvergen mampu menangkap detail objek stimuli dengan baik, banyak membutuhkan fakta riil untuk membuat suatu kesimpulan, lebih mementingkan struktur dan kepastian, serta menggunakan bahasa dan logika dalam berpikir. Pemikir konvergen cenderung menyukai tugas-tugas praktis, kegiatan yang terstruktur, bekerja dengan fakta, berpikir \& bertindak secara bertahap, serta memandang setiap persoalan secara serius.
Cara berpikir konvergen adalah cara berpikir dimana seseorang didorong untuk menemukan jawaban yang benar atas suatu permasalahan. Cara berpikir konvergen nyaris terfokus, intens, cepat, dan terbatas pada informasi yang tersimpan dalam lokasi memori tertentu. Strategi ini diperlukan untuk menyelesaikan tugastugas yang berhubungan dengan angkaangka, memecahkan masalah analogi verbal, atau mengingat ejaan ("spelling") dari suatu kata, dan berkaitan dengan kemampuan intelektual.

Berdasarkan uraian di atas dapat dinyatakan bahwa cara berpikir konvergen secara umum memiliki karakteristik; (a) vertikal, artinya bergerak secara bertahap, (b) konvergen, terfokus menuju pada jawaban yang paling benar, (c) sistematis - terstruktur, logis rasional empiris, (e) dependen, dan (f) teramalkan.

\section{Berpikir Divergen}

Cara berpikir divergen adalah pola berpikir seseorang yang lebih didominasi oleh berfungsinya belahan otak kanan, berpikir lateral, menyangkut pemikiran sekitar atau yang menyimpang dari pusat persoalan (Crowl, Keminsky, and Podell, 1997:5). Berpikir divergent adalah berpikir kreatif, berpikir untuk memberikan bermacam kemungkinan jawaban berdasarkan informasi yang diberikan dengan penekanan pada kuantitas, keragaman, dan orijinalitas jawaban (Utami Munandar, 1992:231). Cara berpikir divergen menujuk pada pola berpikir yang menuju ke berbagai arah dengan ditandai oleh adanya kelancaran ("fluency"), kelenturan ("flexibility"), dan keaslian ("originality") (Briggs and Moore, 1993:24).

Cara berpikir divergent adalah pencarian strategi yang memiliki fokus luas yang memungkinkan terjadinya hubungan antar schemata yang semestinya tidak terjadi hubungan (Enwistle, 1981:67). Hal ini hanya dimungkinkan kalau pencarian itu dilakukan dalam suasana rilek, perlahan, 
dengan leluasa, dan tidak terbatas pada informasi-informasi yang tersimpan dalam lokasi memori tertentu. Dalam konteks ini proses berpikir kreatif di mana kemampuan untuk mencari hubungan-hubungan baru, kombinasi-kombinasi baru antar unsur, data, dan hal-hal yang sudah ada sebelumnya untuk menjawab suatu persoalan menjadi salah satu bentuk riil dari cara berpikir divergen.

Berdasarkan uraian di atas dapat dinyatakan bahwa cara berpikir divergent secara umum memiliki karakteristik; (a) lateral, artinya memandang suatu persoalan dari beberapa sisi, (b) divergen menyebar ke berbagai arah untuk menemukan banyak jawaban, (c) holistik - sistemik, bersifat menyeluruh - global, (c) intuitif - imajinatif, (d) independen, dan (e) tidak teramalkan ("unpredictable").

Cara berpikir adalah refleksi dari perbedaan individual dalam memproses dan mengolah informasi serta penggunaan strategi untuk merespons suatu stimuli atau memecahkan masalah tertentu. Orang diklasifikasikan sebagai individu dengan cara berpikir divergen atau konvergen berdasarkan performasi yang ditunjukkan dalam mengerjakan suatu tugas atau tes tertentu, kuat lemahnya kecenderungan itu dapat dilihat dari proses bagaimana individu menangani situasi-situasi lainnya (Briggs and Moor, 1993:59).

Berkenaan dengan upaya mengidentifikasi kecenderungan cara berpikir seseorang, Entwistle mengemukakan bahwa setiap orang berbeda dalam hal yang penting, yaitu dalam proses klasifikasi sebagai "style of conceptualization" dan dalam orientasinya terhadap kesamaan atau perbedaan sebagai "breadth of categorization" (Enwistle, 1981:65). Perbedaan ini selanjutnya menyebabkan setiap individu berbeda dalam melakukan proses kognisi untuk merespons suatu tugas yang sama. Setidaknya terdapat tiga model kelompok anak, yaitu; 1) anak yang melakukan pengelompokan secara deskriptif, yaitu pengelompokkan berdasarkan ciri-ciri konkrit seperti apa yang nampak dalam bentuk riil yang teramati; 2) anak yang melakukan pengelompokan secara analitis, yaitu pengelompokkan berdasarkan ciri-ciri abstrak dari obyek yang diamati seperti fungsi dan kedudukannya (lokasi); 3) anak yang melakukan pengelompokkan secara rasional atau tematik, yaitu pengelompokkan berdasarkan hubungan fungsional antar objek. Dari ketiga model pengelompokan ini dapat diidentifikasi tentang cara berpikir anak, anak yang bekerja dengan cara pertama dapat diklasifikasikan sebagai individu yang memiliki kecenderungan cara berpikir konvergen, model kedua memiliki kecenderungan cara berpikir moderat, dan model ketiga memiliki kecenderungan cara berpikir divergen.

Proses berpikir untuk menghadapi suatu persoalan atau tugas membutuhkan keduanya (divergen-konvergen). Fungsi divergen diperlukan untuk dapat menghasilkan kemungkinan jawaban yang sebanyak-banyaknya, sementara pemikiran konvergen diperlukan untuk memberikan penilaian secara kritis analitis terhadap hasil pemikiran divergen sehingga dicapai kebenaran. Hubungan fungsional antara berpikir divergen dan konvergen diilustrasikan dalam bentuk Gambar 1.

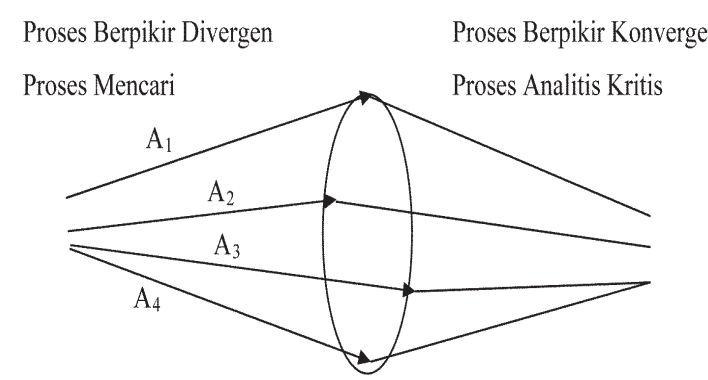

Gambar 1: Proses Berpikir Divergen dan Konvergen sebagai Satu Kesatuan (Conny R. Semiawan, 1997:55)

\section{Model Pembelajaran Konstruktivis- tik \\ Menurut Glasersfeld (1988:102) penger- tian konstruktif kognitif muncul pada abad}


20 dalam tulisan Baldwin yang secara luas diperdalam dan disebarkan oleh Piaget. Namun bila ditelusuri lebih jauh, gagasan pokok konstruktivisme sebenarnya telah dimulai oleh Vico, seorang epistemolog dari Italia. Tahun 1710, Vico dalam De Antiquissima Italorum Sapientia, mengungkapkan filsafatnya dengan berkata, "Tuhan adalah pencipta alam semesta dan manusia adalah tuan dari ciptaan." Dia menjelaskan bahwa mengetahui berarti mengetahui bagaimana membuat sesuatu. Ini berarti bahwa seseorang itu baru mengetahui sesuatu jika ia dapat menjelaskan unsur-unsur apa yang membangun sesuatu itu. Menurut Vico, hanya Tuhan sajalah yang dapat mengerti alam raya ini karena hanya Dia yang tahu bagaimana membuatnya dan dari apa Ia membuatnya. Sementara itu manusia hanya dapat mengetahui sesuatu yang telah dokonstruksikannya. Pengetahuan selalu menunjuk kepada struktur konsep yang dibentuk. Berbeda dengan kaum empirisme yang menyatakan bahwa pengetahuan itu harus menunjuk kepada kenyatan luar. Menurut Vico pengetahuan tidak lepas dari manusia (subyek) yang tahu.

Menurut pandangan konstruktivis, belajar merupakan proses aktif pemelajar mengkonstruksi arti baik teks, dialog, maupun pengalaman fisis. Belajar merupakan proses mengasimilasikan dan menghubungkan pengalaman atau bahan yang dipelajari dengan pengertian yang sudah dipunyai seseorang sehingga pengertiannya dikembangkan. Proses tersebut antara lain memiliki ciri-ciri berikut: 1) belajar berarti membentuk makna, 2) konstruksi arti merupakan proses yang terus-menerus, 3) belajar bukan kegiatan mengumpulkan fakta, melainkan lebih suatu pengembangan pemikiran dengan membuat pengertian yang baru, 4) proses belajar yang sebenarnya terjadi pada waktu skema seseorang dalan keraguan yang merangsang pemikiran lebih lanjut, 5) hasil belajar dipengaruhi oleh pengala- man pemelajar dengan dunia fisik dan lingkungannya, 6) hasil belajar seseorang bergantung pada apa yang telah diketahui pemelajar: konsep-konsep, tujuan, dan motivasi yang mempengaruhi interaksi dengan bahan yang dipelajari (Paul Suparno, 1997:29).

Menurut kaum konstruktivis, pembelajaran bukanlah memindahkan pengetahuan dari guru ke siswa, melainkan suatu kegiatan yang memungkinkan siswa membangun sendiri pengetahuannya. Guru dituntut berpartisipasi dengan siswa dalam membentuk pengetahuan, membuat makna, mencari kejelasan, bersikap kritis, dan mengadakan justifikasi. Seorang guru berperan sebagai mediator dan fasilitator yang membantu agar proses belajar berjalan dengan baik. Fokus proses belajar ada pada diri siswa yang belajar dan bukan pada guru.

Agar peran dan tugas sebagai fasilitator dan mediator berjalan optimal, diperlukan beberapa kegiatan yang perlu dikerjakan dan beberapa pemikiran yang perlu disadari oleh guru, antara lain: 1) guru perlu banyak berinteraksi dengan siswa untuk menggali dan lebih mengerti tentang yang sudah mereka ketahui dan pikirkan, 2) tujuan pembelajaran yang akan dicapai sebaiknya dibicarakan bersama dengan siswa sehingga keterlibatan siswa lebih substansial, 3) guru perlu mengerti pengalaman pembelajaran mana yang lebih sesuai dengan kebutuhan siswa, 4) diperlukan keterlibatan guru bersama siswa yang sedang berjuang dan meyakinkan siswa bahwa mereka dapat belajar, 5) guru perlu memiliki pemikiran yang fleksibel untuk dapat mengerti dan menghargai pemikiran siswa, karena bukan tidak mungkin siswa berpikir berdasarkan pengandaian yang tidak diterima guru.

\section{METODE}

Metode yang digunakan dalam penelitian ini adalah pendekatan R \& D (Research and Development) dengan langkah-langkah; 
1) research and information collecting, 2) planning, 3) develop preliminary from of product, 4) preliminary field testing, 5) main product revision, 6) main field testing, 7) operational product revision, 8) operational field testing, 9) final product revision, and 10) dissemination and implementation (Borg and Gall, 1983:775). Kesepuluh langkah tersebut diringkas menjadi lima langkah utama, yaitu; 1) studi pendahuluan, yang meliputi mengkaji teori-teori yang relevan dan melakukan survei di beberapa SD untuk memotret model pembelajaran yang diterapkan, 2) mengembangkan "model pembelajaran konstruktivistik (hipotetik)" yang disesuaikan dengan karakteristik dan kebutuhan SD, 3) uji coba "model pembelajaran konstruktivistik (hipotetik)", 4) validasi produk "model pembelajaran konstruktivistik", dan 5) melakukan sosialisasi dan deseminasi "model pembelajaran konstruktivistik"

Subyek yang terlibat dalam penelitian ini adalah siswa, guru, dan kepala sekolah. Siswa sebagai subyek utama berperan sebagai individu yang akan dikembangkan potensinya agar dapat berpikir konvergen dan divergen secara seimbang. Siswa dalam penelitian ini adalah siswa kelas 3-5 SD di wilayah kabupaten Sleman, DIY. Guru berperan sebagai aktor yang akan melaksanakan rancangan model pembelajaran, dan mengevaluasi model pembelajaran konstruktivistik bersama dengan peneliti secara kolaboratif. Kepala sekolah berperan sebagai pendukung pelaksanaan model pembelajaran konstruktivistik.

Data yang akan digali dan diolah dalam penelitian ini meliputi data tentang; kecenderungan cara berpikir siswa (konvergen-divergen), sistem evaluasi pembelajaran, aktivitas belajar siswa dalam proses pembelajaran, dan hasil belajar siswa. Sumber data yang diperlukan untuk menggali data antara lain; kepala sekolah, guru, dan siswa

Teknik pengumpulan data yang digunakan dalam penelitian ini adalah; angket, observasi, dan tes. Angket digunakan untuk mengungkap data tentang kecenderungan cara berpikir siswa. Observasi dilakukan untuk mengungkap data tentang aktivitas belajar siswa. Sementara itu tes digunakan untuk mengungkap data tentang kemajuan belajar siswa. Instrumen pengumpul data yang digunakan dalam penelitian ini meliputi; angket, lembar pengamatan, dan tes.

Data yang terkumpul dianalisis secara deskriptif kuantitatif, dengan maksud untuk mengetahui kecenderungan dari tiap-tiap 'variabel' penelitian.

\section{HASIL DAN PEMBAHASAN \\ Kecenderungan Cara Berpikir Siswa}

Skala cara berpikir siswa diukur dengan instrumen angket sebanyak 38 butir. Pada setiap butir disediakan tiga alternatif jawaban yaitu; YA, TIDAK, dan MENGISI TITIK-TITIK. Jika sebagian besar butir dijawab YA atau TIDAK mengindikasikan bahwa siswa memiliki kecenderungan berpikir konvergen dan jika sebagian besar butir dijawab dengan cara mengisi TITIKTITIK yang disediakan mengidikasikan bahwa siswa memiliki kecenderungan berpikir divergen. Contoh: Sampah harus dibuang di tempat sampah. Bagi yang cenderung berpikir konvergen akan menjawab YA atau TIDAK, tetapi bagi yang cenderung berpikir divergen mungkin akan mengisi kolom TITIK-TITIK dengan jawaban Sampah plastik dan logam tidak harus dibuang.

Sebelum dilakukan ujicoba model pembelajaran konstruktivistik yang sifatnya masih hipotetik, kecenderungan cara berpikir siswa kelas 3, kelas 4, dan kelas 5 masih cenderung konvergen. Sebab sebagian besar siswa dalam merespon angket masih memilih alternatif YA atau TIDAK. Hanya sebagian kecil saja yang dalam merespon angket mengisi kolom TITIK-TITIK. Tetapi setelah dilakukan ujicoba penerapan model pembelajaran yang sifatnya masih hipotetik, terjadi peningka- 
tan kasus pengisian alternatif TITIK-TITIK antara pertemuan 1 dengan pertemuan 2 . Kelas 3 mengalami peningkatan pengisian kolom TITIK-TITK yang cukup tinggi (dari 39 kasus menjadi 123 kasus). Begitu juga kelas 4 dari 50 kasus menjadi 175 kasus, sementara itu kelas 5 terjadi peningkatan dari 59 kasus menjadi 181 kasus.

\section{Model Pembelajaran}

Model pembelajaran yang sering diterapkan guru adalah model pembelajaran ekspositori, yang menjadikan metode ceramah sebagai metode utama. Guru sangat dominan, aktivitas siswa cenderung rendah (pasif), dan potensi siswa tidak dapat berkembang secara optimal. Guru sering menggunakan pendekatan behavioristik dan jarang menggunakan pendekatan konstruktivistik.

Model pembelajaran konstruktivistik dalam penelitian ini menjadikan guru sebagai mediator dan fasilitator. Fungsi mediator dan fasilitatator dapat dijabarkan dalam beberapa tugas sebagai berikut:

a. Menyediakan pengalaman belajar yang memungkinkan siswa bertanggung jawab dalam membuat rancangan, proses, dan penelitian.

b. Menyediakan atau memberi kegiatan yang merangsang keingintahuan siswa, membantu mereka untuk mengekspresikan gagasannya, dan mengkomunikasikan ide ilmiah mereka. Menyediakan sarana yang merangsang siswa berpikir secara produktif. Menyediakan kesempatan dan pengalaman yang mendukung proses belajar siswa.

c. Memonitor, mengevaluasi, dan menunjukkan apakah pemikiran siswa berjalan atau tidak. Guru menunjukkan dan mempertanyakan apakah pengetahuan siswa berlaku untuk menghadapi persoalan baru yang relevan. Guru membantu mengevaluasi hipotesis dan kesimpulan siswa.

\section{Aktivitas Belajar Siswa}

Guru kelas 3, kelas 4, dan kelas 5 bersama peneliti merekam aktivitas siswa dalam pembelajaran. Aktivitas yang direkam meliputi aktivitas; bertanya, berpendapat, menjawab pertanyaan, melakukan percobaan, melakukan pengamatan, dan mengerjakan tugas di kelas. Deskripsi aktivitas siswa dapat diamati melalui Tabel 1, Tabel 2, dan Tabel 3.

Terjadi peningkatan aktivitas belajar siswa antara pertemuan ke-1 dengan pertemuan ke-2. Meskipun peningkatannya belum optimal setidaknya model pembelajaran konstruktivistik yang sifatnya masih hipotetik ini memberikan hasil yang dapat dipertanggungjawabkan.

Tabel 1. Aktivitas Belajar Siswa Kelas 3

\begin{tabular}{llcc}
\hline NO & AKTIVITAS & PERTEMUAN PERTEMUAN \\
& & 1 & 2 \\
\hline 1 & Bertanya & $14 \%$ & $17 \%$ \\
2 & Berpendapat & $12 \%$ & $16 \%$ \\
3 & Menjawab pertanyaan & $19 \%$ & $21 \%$ \\
4 & Melakukan percobaan & $14 \%$ & $15 \%$ \\
5 & Melakukan & $16 \%$ & $19 \%$ \\
& pengamatan & & \\
6 & Mengerjakan tugas di & $87 \%$ & $91 \%$ \\
\hline
\end{tabular}

Tabel 2. Aktivitas Belajar Siswa Kelas 4

\begin{tabular}{llcc}
\hline NO & \multicolumn{1}{c}{ AKTIVITAS } & PERTEMUAN PERTEMUAN \\
& & 1 & 2 \\
\hline 1 & Bertanya & $16 \%$ & $18 \%$ \\
2 & Berpendapat & $15 \%$ & $16 \%$ \\
3 & Menjawab pertanyaan & $11 \%$ & $15 \%$ \\
4 & Melakukan percobaan & $13 \%$ & $14 \%$ \\
5 & Melakukan & $17 \%$ & $19 \%$ \\
& pengamatan & & $92 \%$ \\
6 & $\begin{array}{l}\text { Mengerjakan tugas di } \\
\text { depan kelas }\end{array}$ & $91 \%$ & \\
\hline
\end{tabular}

Tabel 3. Aktivitas Belajar Siswa Kelas 5

\begin{tabular}{|c|c|c|c|}
\hline \multirow[t]{2}{*}{ NO } & \multirow[t]{2}{*}{ AKTIVITAS } & \multicolumn{2}{|c|}{ PERTEMUAN PERTEMUAN } \\
\hline & & 1 & 2 \\
\hline 1 & Bertanya & $18 \%$ & $20 \%$ \\
\hline 2 & Berpendapat & $17 \%$ & $19 \%$ \\
\hline 3 & Menjawab pertanyaan & $16 \%$ & $20 \%$ \\
\hline 4 & Melakukan percobaan & $19 \%$ & $22 \%$ \\
\hline 5 & $\begin{array}{l}\text { Melakukan } \\
\text { pengamatan }\end{array}$ & $11 \%$ & $19 \%$ \\
\hline 6 & $\begin{array}{l}\text { Mengerjakan tugas di } \\
\text { depan kelas }\end{array}$ & $94 \%$ & $94 \%$ \\
\hline
\end{tabular}




\section{Hasil Belajar}

Hasil belajar dalam hal ini dimaknai sebagai skor tes tertulis yang dilakukan guru pada setiap akhir pertemuan untuk mengukur tingkat penguasaan siswa memahami materi yang baru saja dipelajari. Hasil belajar siswa kelas 3, kelas 4, dan kelas 5 dapat dicermati pada Tabel 4 .

Tabel 4. Hasil Belajar Siswa

\begin{tabular}{ccc}
\hline KELAS & RERATA SKOR & RERATA SKOR \\
& PERTEMUAN I & PERTEMUAN II \\
\hline 3 & 7.08 & 7.70 \\
4 & 6.97 & 7.70 \\
\hline 5 & 7.08 & 7.61 \\
\hline
\end{tabular}

Dari Tabel 4 terlihat bahwa baik di kelas 3, kelas 4, maupun kelas 5 terdapat peningkatan rata-rata pencapaian hasil belajar antara pertemuan I dengan pertemuan II (meskipun kenaikannya tidak terlalu signifikan). Hal ini menunjukkan bahwa model pembelajaran hipotetik ini perlu penyempurnaan agar peningkatan hasil pembelajarannya lebih signifikan.

\section{Sistem Penilaian Portofolio}

Selama uji coba model guru kelas 3, kelas 4, dan kelas 5 dalam menilai kemampuan siswa tidak hanya berdasarkan pada tes tertulis, melainkan juga menggunakan portofolio sebagai alat penilaian. Guru merekam semua aktivitas siswa dalam pembelajaran sebagai bahan pertimbangan untuk menentukan skor akhir siswa pada mata pelajaran Sains.

Hal-hal yang direkam sebagai bahan pertimbangan menentukan skor akhir siswa pada mata pelajaran Sains adalah tugas individual, tugas kelompok, dan aktivitas siswa dalam proses pembelajaran. Tugas individual dalam hal ini meliputi: pekerjaan rumah, hasil pekerjaan individual dalam bentuk isian format yang telah disiapkan guru, dan laporan pengamatan individual siswa. Tugas kelompok dalam hal ini meliputi: hasil pekerjaan kelompok dalam bentuk isian format yang disiapkan guru, laporan pengamatan kelompok, dan laporan hasil percobaan secara kelompok oleh siswa. Aktivitas siswa dalam hal ini berupa skor hasil pengamatan guru tentang aktivitas siswa secara individual selama mengikuti proses pembelajaran.

Penerapan sistem penilaian portofolio mampu meningkatkan aktivitas belajar siswa SD. Hal ini wajar sebab siswa selalu berupaya untuk melakukan aktivitas tertentu agar aktivitas yang dilakukan itu direkam oleh guru sehingga menambah perolehan sekor akhir pada mata pelajaran Sains.

\section{PENUTUP}

Berdasarkan temuan dan pembahasan, penelitian ini menyimpulkan beberapa hal sebagai berikut: 1) pembelajaran di SD Sleman lebih dominan mengembangkan cara berpikir konvergen daripada cara berpikir divergen, 2) model pembelajaran yang sering diterapkan guru adalah model pembelajaran ekspositori, yang menjadikan metode ceramah sebagai metode utama, 3) penerapan model pembelajaran konstruktivistik mampu meningkatkan cara berpikir divergen dan konvergen siswa $\mathrm{SD}, 4)$ penerapan model pembelajaran konstruktivistik mampu meningkatkan aktivitas belajar siswa SD, 5) penerapan model pembelajaran konstruktivistik mampu meningkatkan hasil belajar siswa SD, dan 6) sistem evaluasi portofolio mampu meningkatkan aktivitas belajar siswa SD.

\section{Saran}

Berdasarkan temuan penelitian dan implikasi penelitian, maka dapat diajukan beberapa saran sebagai berikut; 1) perlu pelatihan yang intensif bagi guru SD tentang model pembelajaran konstruktivistik agar guru mampu menerapkan dengan baik dan benar, 2) sistem penilaian portofolio sebagai penilaian otentik (authentic assessment) dengan berbagai pengukuran (multiple measures) dalam konteks yang 
bervariasi perlu diterapkan, dan 3) perlu penelitian lebih lanjut pada tahun berikutnya untuk memantapkan model pembelajaran konstruktivistik yang sifatnya masih hipotetik.

\section{DAFTAR PUSTAKA}

Borg, Walter R and Meredith D. Gall. (1983). Educational Research. New York: Longman Inc.

Briggs, John B. and Phillip J. Moore. (1993). The Process of Learning. Sidney Australia: Prentice Hall.

Conny R. Semiawan. (1997). Perspektif Pendidikan Anak Berbakat. Jakarta: Gramedia Widiasarana Indonesia.

Crowl, Keminsky, and Podell. (1997). Educational Psychology: Windows on Teaching, Dubuque. IA: Times Mirror Higher Education Group.
Enwistle. (1981). Style of Learning and Teaching. Great Britain: John Wiley \& Sons, Ltd.

Glasersfeld, Von. (1988). Cognition, Construction of Knowledge, and Teaching. Washington D.C.: National Science Foundation.

Paul Suparno. (1997). Filsafat Konstruktivisme dalam Pendidikan. Yogyakarta: Penerbit Kanisius.

Utami Munandar, S.C.. (1992). Mengembangkan Bakat dan Kreativitas Anak Sekolah, Petunjuk bagi Guru dan Orang Tua. Jakarta: Gramedia Widiasarana Indonesia.

Winarno Surakhmad, dkk.. (2003). Mengurai Benang Kusut Pendidikan. Jakarta: Transformasi UNJ. 